\title{
The Impact of Kurdish Referendum on the Driving Forces of Turkish Foreign policy Toward KRG
}

\author{
Shokhan Sherzad Qader \\ PhD Student - Department of Political Science - Faculty of Law, Political Science and \\ Management - Soran University - Iraq \\ Email: shokhan.sherzad@gmail.com
}

\section{Prof. Dr. Mohammed Ihsan}

Senior Research Fellow at Defense Studies Research - King's College - London - England Email: mohammed.ihsan@ue.edu.krd

\begin{abstract}
The justice and Development party (AKP - Adalet ve Kalkinma Partisi) has been the ruling party from the first elections they contested in 2002. Turkey's policy has changed throughout the time, especially after AKP has been the ruling party continually since 2002, major shifts could be noticed. More importantly the dimensions of Turkey's policy in the Middle East transferred to a broader status, especially when Turkey turned away to EU; at the same time EU started to review their policy toward Turkey, this impacted Turkey to focus more on the Middle East issues. So Turkey could be clearly seen that it has been presented in many countries and many events and changes in the Middle East, such as Syria, Iraq and the rest. Kurdistan Regional Government (KRG) as a part of that has taken its share in this policy orientation by Turkey, especially when the prominent personality Ahmet Davutoglu started to apply his "Strategic Depth" doctrines and declared for "zero problems" with neighbors, at the same time Turkey has set some priorities for their foreign policy orientation and those orientation is containing some driving forces of foreign policy toward the neighboring countries. So these driving forces had started to shape the Turkish foreign policy toward Middle East and particularly toward KRG, and this had led to very strong relations in many aspects till the referendum. However when KRG underwent a referendum in $25^{\text {th }}$ September 2017 in order to completely split from Iraq and establish its own state. Turkey, which is one of the countries that has great significance in many aspects for KRG, too, opposed the referendum. That's why after the referendum a very clear deterioration could be noticed temporarily, but due to politico -economic relations, Turkey's soft instrument foreign policy, and security emphasis led the relations of both sides to still stay in a stable condition.
\end{abstract}

Keywords: Turkey, AKP, KRG, Foreign policy, Referendum. 


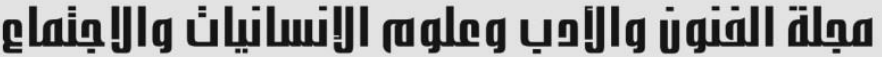

Journal of Arts, Literature, Humanities and Social Sciences

www.jalhss.com

Volume (54) July 2020

العدد (54) يوليو 2020

\section{INTRODUCTION}

In 2002 for the first time AK party by winning 34 percent of votes could gain 363 seats of Parliament and establish its new government. But one of the main constraints that has been facing the AKP government. Both inside and outside the country was the Kurdish issue, and this issue has directly impacted the Turkish policy.

The invasion of Iraq in 2003, was a turning point for overviewing Turkish foreign policy toward the Kurdistan region, because Turkey faced a reality after the destruction of Iraq and the collapse of governmental institutions. This fact led Turkey to review its past policies, because in the new Iraq Kurds gained an important identity in the new Iraqi equation policy. In this equation the Kurdish issue has raised awareness both regionally and internationally, particularly because of its important strategic geo - politic and economy.

But when AK Party came to power in 2002, it was obvious that a new period has been started in Turkish Foreign Policy, which, until that time, had mostly been described as non-interventionist, western-oriented, and security centered policies. The transformation was more noticeable especially after Ahmet Davutoglu's "Strategic Depth" doctrine which was mostly declaring for "zero problems with the neighbors". This policy impacted Turkish Foreign policy and started to re-arrange the relations in the region and shift the attention to the Middle East. This has also led the international community and the researchers to consider if Turkey wants to assess its relations with the West and emphasis more on the Middle East.

Before AKP government, Turkey was in devastation of economy, and economic development was one of the main tools for AKP to continue in forwarding success of their policy, and KRG was one of the options for them to build strong economic relations. However the ties between two sides has very broader dimensions, and that's right time to time there were ups and downs in relations of both sides but holding referendum by the KRG has raised questions if the Turkish officials to reassess their relations all over.

So this piece of work tries to answer these questions below;

1. What are the driving forces of Turkish foreign policy toward KRG (Kurdistan Regional Government) since 2002, with the coming of AK party to the power?

2. How the Kurdish Referendum has been affected to the relations of both sides?

This paper argues that Turkey has many important driving forces toward KRG such as economy, energy, and cultural ties. But more importantly these driving forces has been divided to some eras since the AK party's victory, so in every era the conjecture of Middle East and problems inside Turkey significantly impacted on the 


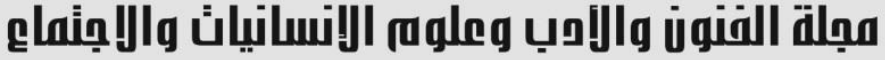 \\ Journal of Arts, Literature, Humanities and Social Sciences www.jalhss.com

reactions of Turkey Toward KRG. So the reactions of Turkey regarding the Kurdish referendum was based on the circumstances of Turkey, especially the demand of the population inside Turkey. Above all, even after the referendum due to Turkey's politico- economic emphasis, Turkey's soft instruments foreign policy, and security issues led Turkey to be driven by these forces in its foreign policy and to still stay in a stable condition of relations with KRG.

The importance of this study is that, as it is clear Turkey is one of the powerful actors in the Middle East Region, so its policy can impact Kurdistan Regional Government directly, and it's very important to analyze each driving forces of Turkish foreign policy toward KRG since 2002, and then analyze the reactions specifically toward KRG referendum.

This study will undertake a qualitative analysis of historical literature and perspectives on the subject by focusing on Turkey's policy toward KRG. By returning back to the literatures including published journal articles, books, and published researches.

It will also obtain secondary data drawn from reports, working papers, and websites, especially the websites that published by international organizations for foreign policy of Turkey such as SETA foundation for Political, Economic and Social Research, and ORSAM (Center for Middle Eastern Studies). The time frame of this study is focusing on the period when Justice and Development party (AKP Adalet ve Kalkinma Partisi), takes the authority and starts as a ruling party until the present time.

The first part of the study has given an introduction about the main research questions and a general view about the topic, secondly it will be focused on the recent literatures on the foreign policy change attempts, and then a historical overview of the origins of Turkish politics, later on it will highlight the Turkish foreign policy emphasizes which are divided in two three main points, and lastly the concluding remarks will be presented.

\section{Turkey's Foreign Policy Change Attempts}

Recently, so many books, researches and studies have been done about Turkey's foreign Policy generally, and particularly toward Middle East. It's necessary to go back through some literatures that shape the relations of Turkey with neighboring countries in the Middle East in one side, and with the Europe and West in another side. It's important to mention, the literatures will be focused mostly on the studies that have done after 2002, the time when AKP (Adalet ve Kalkinma Partisi) coming as a ruling party to power, but without forgetting Turkey's Ottoman, and the impact of Kemalist past. The literature aims to demonstrate the changes, the dimensions, and the role of Turkey in the Middle East. 


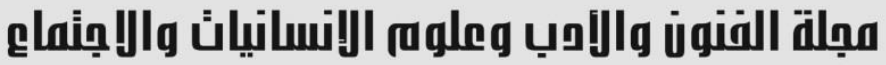 \\ Journal of Arts, Literature, Humanities and Social Sciences www.jalhss.com

Among the works that demonstrate a deep understanding of Turkey's recent foreign policy could be firstly referred back to Ahmet Davutoglu (2001), Turkey's foreign policy since 2002 without revealing back to Davutoglu would be out of worthy, Davutoglu which he was a chief foreign policy advisor to the Prime Minister "Recep Tayip Erdogan", before becoming a foreign minister in 2009, Davutoglu has so many books, and academic works but one of the most prominent one is "Strategic Depth", in which he gives a deep strategic vision with informative and contradictive views about Turkey's Foreign Policy. This strategic depth covers three main aspects such as; geo-cultural, geo-politics, and geo-economic dimensions in analyzing the strategic depth of Turkey's foreign policy. More importantly, he tried to remove the lackness of strategic theories and finding more alternatives in point of views.

In his study Davutoglu, the entitled book as "Strategic Depth", he emphasizes that Turkey possesses "a strategic depth" because of its history and geographical location, Turkey's both geographical location and historical heritage makes it impossible to be an introverted country, these two factors leads Turkey to have a new strategy and a new confidency in its foreign policy. That's why Turkey could be considered in the middle of this position, and it has to have its influence and an active engagement in the region. That's why Davutoglu emphasized on "zero problems" principle with the neighbors, because he thinks in order to play a leading and strategic role in the region there should be good and "friendly" relations with the neighbors (Davutoglu, 2001).

Furthermore, regarding the Middle East he states that; Middle East has a very poorly drawn borders, after first and second World wars Middle East has divided to small units as states, but most importantly after the end of Cold war Middle East started to gain some new characteristics. Moreover he states that Turkey possesses a historical heritage because when compared to Middle Eastern countries are new countries and they don't own such a historical heritage that's why Turkey could have a deep strategic approach in the region. He states that to be in a bad diplomatic relation it's a shortage for a country, that's why Turkey should play not only as a regional actor but also as a central actor, and try to remove all the psychological obstacles, analyze, and develop a deep strategic approach in the region (Davutoglu, 2001).

Moreover he states that Turkey not only has to play as a regional actor, but it has to have a global strategic approach due to its historical and cultural aspects, but in order to achieve this, it has to reconsider both the domestic and foreign relations. Turkey first has to solve its own problems inside the country such as the Kurdish question and the disputes between Islamic and secular groups. Additionally, Turkey should maintain its relations with the countries that have problems and disputes with them, especially with the neighboring countries (Davutoglu, 2001). 


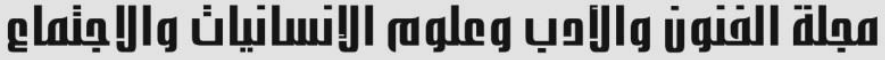 \\ Journal of Arts, Literature, Humanities and Social Sciences www.jalhss.com \\ Volume (54) July 2020 \\ العدد (54) يوليو 2020}

Zenonas Tziarras (2014), in his research Turkish Foreign Policy Towards The Middle East under the AKP (2002 - 2013): A Neoclassical Realist Account states that, Turkish foreign policy after 20002 is one of the debated issue under AKP (Adalet ve Kalkinma partisi), there are two dynamics under AKP toward the Middle East; "system - level dynamics and domestic - drivers", which the system - level dynamics have more influence and includes; international relative power, external threats perceptions of Turkey, and international economic independencies. On the other hand, the domestic drivers which they do not have influence directly and include; AKP elite ideology, and domestic interest groups. Moreover the author adds that it cannot be ignored that there is the impact of "political Islamic ideological incentives", even if it doesn't have a direct impact, that's why Turkey regardless of being the member of NATO and candidate of EU, due to the ideological influence and the volatile and unstable neighbors turned to its own region. Additionally, he states that Turkey tried to play the role of the mediator in the region but it was not successful, especially in the case of Iran and Palestine it took side regardless of its relations with Israel and stood against the West (Tziarras, 2014).

That's why Laciner (2001), in his research draws the attention on the importance of Turkey's "geopolitical location", "past experience", "domestic politics", and "ideologies". All these factors influenced Turkey to have an active and changeable foreign policy, that's why Turkey in each era had different and changeable policy. Moreover these changes could not only refer back to ideology or domestic politics but it could be referred back to domestic changes. That's why not only a single ideology impacted on Turkey's foreign policy but more than one ideology impacted the evolution of the foreign policy like "leftism, conservatism, Islamism, ottomanism, and ozalism" and in each era these ideologies have been applied in Turkey's foreign policy.

These are some general views on Turkish foreign policy change attempts that revealed out by some authors, the change in Turkish foreign policy after AKP has come to power is so much debatable, and not only limited only to the explanations above, but there are major shifts in Turkish foreign policy towards the Middle East, particularly after declaring the "zero problems" with neighbors, the outcome of the policy is more debatable particularly after the Arab uprisings. But it can be derived very clearly Turkey shifted to its neighbors and KRG has taken this share, and the policy toward KRG, and strategic views of Turkey will be revealed in the coming parts of the study.

\section{Historical Overview of Turkey's Politics and its impact on KRG}

Due to the location of the Middle East, the researchers have always focused on this region in their studies. Middle East similar to any region each actor has different dynamics and activities, and care for their relations with the neighbors in different levels and directions. Because of that most of the time some kind of collision occurs 


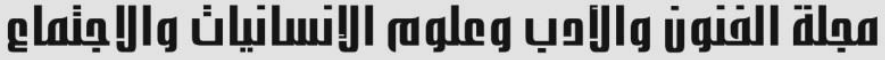 \\ Journal of Arts, Literature, Humanities and Social Sciences www.jalhss.com \\ Volume (54) July 2020 \\ العدد (54) يوليو 2020}

in their relations, and this affects their relations directly. But one of the important points is that, the path to relations and activities have always been open. But during a long history, one of the prominent actors in this region is Turkey, and this started to be more obvious after 2002 .

Above all, there is a very pivotal fact about Turkey's geographical location, which this leads all the International community to shift their attention on Turkey during the history. The modern Turkey is located in such a place where called the heartland of Eurasia. That's why Turkey owns one of the most important strategic areas in the World in terms of its geographical location. Turkey's location has some unique features; Turkey is divided between the continents of Europe and Asia, a small part of it called the Thrace of Europe, while the larger part is called Anatolia and located in Asia. It is located between Greece and Syria, the borders covered by Black sea, Aegean Sea, and the Mediterranean Sea. The other borders covered by Bulgaria, Georgia, Armenia, Azerbaijan, Iran, Iraq and Syria. So this shows that, Turkey is one of the larger countries in terms of territory and having neighbors.

That's why Davutoglu (2008, p.78) highlights the importance of the geographical location in his words;

'In terms of geography, Turkey occupies a unique space. As a large country in the midst of Afro-Eurasia's vast landmass, it may be defined as a central country with multiple regional identities that cannot be reduced to one unified character. Like Russia, Germany, Iran, and Egypt, Turkey cannot be explained geographically or culturally by associating it with one single region. Turkey's diverse regional composition lends it the capability of maneuvering in several regions simultaneously; in this sense, it controls an area of influence in its immediate environs.'

Turkey founded by the ruins of Ottoman Empire, Mustafa Kemal who named as Ataturk as" the father of all Turks". We may not have the ability to predict the future, especially for the case of Turkey, which is surrounded by all these sudden events and sometimes its reactions could be considered out of its capacity and capability. But at least the study and analyzing the history could clear out the path to the future, and led us to try to read, and to have a say about the future.

Turkey since its creation was full of sudden events, especially after the transformation of Turkey from single - party to multi - party system, and the real obvious conflicts started from this point. The military had always had a say in Turkey's political society with its so many justifications, and protecting the Kemalism's legacy. That's why Turkey experiences the most military coups in its modern history, with both successful and failed coups.

Turkey is one of the countries also experiences the most new - opening parties, and later abandonments by the constitutional court after the military coups, 


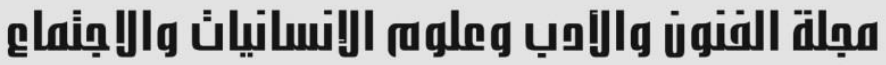 \\ Journal of Arts, Literature, Humanities and Social Sciences www.jalhss.com

the justifications for that again was seeing the parties as a threat to Kemalism's legacy, and especially as a threat to undermining secularism.

However, Most of the authors and analysts consider the era of Turgut Ozal during the years of 1983 - 1993 as one of the most fundamental periods, as he could play his role as both prime minister and president of Turkey in the mentioned period, that's why Cengiz Candar describes Ozal as a "monumental figure" and (2013, p.29) claims him as "the man who carried Turkey from the twentieth and into the twentyfirst century." (Candar 2013, p.29)

Moreover, he is considered as one of the prominent one's in Turkey's History who changed the traditions that's why Candar states that, "by the 1990s, left-wing and right-wing politics did not mean much to Turgut Ozal. His main concern were to innovate, to change (both oneself and others), to challenge and break the taboos and therefore be unconventional, to have the courage to revolt and to be skillful at it. It was particularly this approach that allowed him to have a working relationship with many people with different ideological backgrounds" (Candar 2013, P. 30-31).

According to Kursad Turan (2012 p.73), Ozal's policy during this era mostly motivated by two important factors, especially toward Middle East region, the first is economic motivations, especially after the oil crisis in 1970's Ozal felt for such a need to open up Turkey's economy and to start for the liberalization, secondly, motivations based on security issues, especially in 1980's were under the effect of the Cold War, and the conflicts in the region such as Iraq-Iran war, and Iraq's invasion to Kuwait, Ozal felt that in such a situation Turkey could play its role, and have influences (Turan, 2012).

Moreover, Candar (2013), states that, Ozal after the Cold War, wanted to have more affect geopolitically including Balkans, Middle East, Caucasus, and Central Asia, he was trying to apply Ataturk's principle "Peace in the motherland, peace in the world", and he was one of the one's who was hoping to find a solution for Kurdish issue, and recognizing Kurdish identity (Candar, 2013 p. 32-33), and even federalism was debatable for him in order to solve the Kurdish issue (Heper, 2013 p.142).

This also attempted to start having relations with the both Kurdish political parties, KDP and PUK at Iraq- Kurdistan; they even opened their offices at Ankara (Candar, 2013). These developments lead the PKK to announce for the ceasefire for the first time in 1993, this was a reaction by the group for the message of "Kurdish opening", and were hoping for a solution (Karatasli, 2015, p. 408). But unfortunately due to the sudden death of Ozal, all these attempts were suspended, and the Kurdish issue stayed as one of the top disputed issues in Turkey's politics (Karatasli, 2015).

Turkey's traditional, mono-dimensional foreign policy was developed after Turkey became a republic in 1923 with the view of modernizing the country. Because Turkey had not encountered any influential alternative, it maintained this Westernoriented, on-sided foreign policy until post-Cold War when geopolitical and global challenges emerged. In response to these challenges, Turkey began to redefine its priorities and principles in the domain of foreign policy in an effort to position itself as a major player. This became more pronounced when the AKP won 2002 elections 


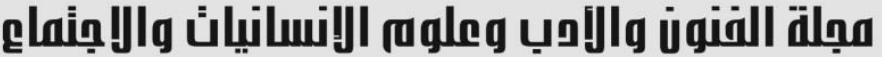

Journal of Arts, Literature, Humanities and Social Sciences

www.jalhss.com

Volume (54) July 2020

العدد (54) يوليو 2020

and formed government. Under the AKP, Turkey has revived its strategic and geopolitical position as a major player and redefined its geo-strategic coordinates in more suitable ways. According to Mahmoud Khalifa (2017), the new Turkey foreign policy follows Davutoglu's strategic depth vision which seeks encourages zeroproblems with neighborhood, seeking proactive and multidimensional policies in the wider region and using heritage of Ottoman Empire as an asset it is policy to grow its influence in the region. It also uses soft power instruments improve relations and reach out to its neighborhoods.

\section{The Emphasizes of Turkish Foreign Policy toward KRG}

There are three main eras which starts from the beginning of 2002 by the coming of AK party to the power, it can be divided as three periods such as $2002-$ 2007, in this era Turkey was mostly emphasizing on Democracy that's why it started to fasten the discussions with the EU so this impacted on the relations with the Kurdish population and reacted on the relations with KRG.

The second era starts from 2007 - 20013, this era Turkey started to emphasize on Middle East region, and started to directly intervene to the issues of Middle East, on the other hand Ahmed Davutoglu insisting on having "zero problems" with the neighbors, and this reacted directly to the diplomatic relations with KRG.

The third era after the Arab Spring, while Turkey intervening directly to the Middle East issues, but faced too many security issues such as the rise of the terrorist group of ISIS, and too many conflicts in the Middle East both with state and non state actors. For all of these reason Turkey started to worry about its territorial security, coincidently the Kurdish referendum in Kurdistan Regional of Iraq started to be held. On the other hand AK party had to also gain its population again, and reconsider its policy with the neighbor.

So in more detail the emphasizes of Turkish foreign policy could be divided in to three points below;

\section{The Democratic and Economic Emphasis}

This section focuses on politico-economic developments in the country driving the new foreign policy. After taking the reign of power, the AKP regime carried out several reforms that elevated Turkey to a level of a global leader. With the majority in Parliament, AKP succeeded in passing major legislative amendments, while pursuing a foreign policy that decides on Turkey's EU access. The AKP regime was full awareness of post-Cold War challenges and dynamics when choosing the course that Turkish foreign policy had to take. Elhusseini (2018) identifies two drivers behind the transformation of Ankara's new foreign policy under the AKP regime. The first is rapidly economic growth that enabled Turkey to apply her soft 


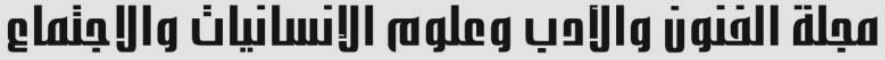 \\ Journal of Arts, Literature, Humanities and Social Sciences www.jalhss.com

power capability as a foreign policy instrument. The second is domestic politics, especially the Kurdish question (Elhusseini, 2018).

Turkey carried out economic changes that improved trade and economic ties with the neighbors. Turkey implemented many policy measures to boost its economic relations with the neighbors. Some of these measures include visa-free, bilateral investment and trade agreements with the neighbors. One of the remarkable achievements of the AKP regime has been minimizing the influence of the military and transferring that influence to civilian control. This has served to limit the impact of the military to shape security priorities, enabling the AKP regime to soften its aggressive approach to neighboring countries once regarded as the adversaries of Turkey.

Democratization has helped soften Kurdish question in Ankara and resulted in compromise. The Kurdish conflict had caused exhaustion and weariness in Turkish society. The AKP elite and Kurdish personalities have realized security-based approach and brutality would not address the problem (Demir, 2017). As a result, there have been attempts to address this problem in more democratic way. In response, the AKP has attempted to use liberal principles to address the problem and this has led to Kurdish cultural and political demands to be partially met. In 2009, the AKP launched Kurdish-Language state broadcasting station and also allowed PKK radicals to return home from northern Iraq (Grigoriadis, 2010).

Irrespective of drawbacks faced, the foreign policy of the AKP has achieved some impressive achievements. It stabilized its diplomatic relations on strong domestic foundations. For example, systems that drove positive economic growth have allowed Turkey to create multiple trade and economic partnerships globally. The political stability enjoyed during this period projected the country as a role model for the region. By selling the notion of zero problems with the region and distancing itself from the West, Turkey succeeded in improving its diplomatic ties with the neighbors. So all of these changes could be noticed very clearly with KRG, and improving their economic ties, and they have reached the highest peak in their diplomatic relations.

\section{Turkey's Soft Instrument Foreign Policy}

Girgoriadis (2010) argues that Turkey's foreign policy is a continuation of proactive strategy under Ozal only that this time around it has a more comprehensive vision. Davutoğlu has formulated the TFP along with policy mechanisms to address and adjust to challenges of post-Cold War era. Foreign policy envisaged by Davutoğlu contains liberal concepts like conflict resolution, win-win-solutions, and soft power (Grigoriadis, 2010).

Turkey's soft balancing has growing rapidly as evidenced by its engagement in many new places in the Arab world. It has engaged in mediation efforts in the neighborhoods, such as between Israel and Syria (Akay and Yilmaz 2013). Turkey's 


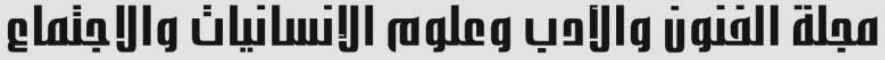 \\ Journal of Arts, Literature, Humanities and Social Sciences www.jalhss.com

pro-active policy is in proportion to its historical geographic depth and seeks to revive Ottoman legacy (Grigoriadis, 2010). The policy is designed to project Turkey's soft balancing potential hinged on historical and cultural bonds with the neighborhood (Grigoriadis, 2010). Turkey has demonstrated its soft power potential in conflict resolution, promoting international peace, and strengthens economic relations with its neighbors and thus improved its standing in the region (Malinauskas, 2015). Having abandoned military tactics, as well as the employment of military tutelage, Turkey has been forging economic relations and cooperation with the neighbors and made some inroads (Grigoriadis, 2010).

One example where Turkey has exercised its soft power in conflict resolution involves the Kurdish question. In its pursuit for peaceful dispute resolution, Turkey has attempted to resolve Kurdish problem and to diffuse the increasing tension between Islamist and secularist elements using liberal principles (Grigoriadis, 2010). Davutoğlu advocated for the use of liberal principles in solving Kurdish question thus ensuring their minority rights are respected and protected. In addition to improving relations with the Kurdish Regional Government, Turkey used its soft balancing capability to mediate between Syria and Israel, Iran and the West over the Iranian nuclear program. On the case of Iran, Turkey urged the US and EU to find a solution agreeable to both sides without using sanctions. Turkey even reached an agreement with Iran but the West rejected the deal and announced new sanctions on Iran. The Syrian-Israel case never materialized because of Israel's actions that forced Turkey to change its role as a neutral mediator to siding with Syria. Furthermore, Turkey tried to play mediator roles between the Sunni and Shia conflicts in Iraq in order to reach a resolution.

\section{The Security Emphasis}

After 9/11, tension escalated between the Muslim and the West, as evidenced by increasing Islamophobia (Tziarras, 2014). The 9/11 episode, along with the reaction of the US and the campaign of war on terrorism resulted in drastic sweeping structural transformations in the Middle East. The prioritization of Islamic terrorism as a security threat accompanied by the invasion of Afghanistan in 2001 elevated Turkey as a strategic partner of the US and its allies (Tziarras, 2014). Turkey itself supported the fight against terrorism by allowing the US to use its airspace. The 2003 invasion of Iraq by the US-led allies had an enormous effect on Turkish foreign policy. To start with, member-states of the EU and NATO expressed different opinions about the invasion because the UN did not support it (Tziarras, 2014). Secondly, the Iraq invasion exposed the disagreement in Middle East interests between Turkey and America while it set free competing sectarian and geopolitical dynamics (Tziarras, 2014).

The invasion of Iraq empowered the Kurdish and increased their chances of achieving long-lasting autonomy, the worst that Turkey feared could happen. Concerning the balance of power in the region, Tziarra (2014) argues "this development enhanced the US-Israel relative power weight vis-à-vis Turkey's 


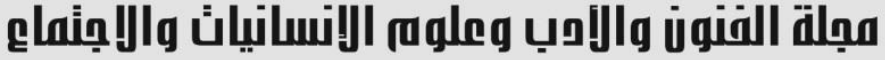 \\ Journal of Arts, Literature, Humanities and Social Sciences www.jalhss.com

position as the US filled the power vacuum in Iraq" (140). In other words, AKP's proactive foreign policy was informed by the post-9/11 geopolitics (Tziarras, 2014). The geopolitical aftershock of 2003 invasion of Iraq greatly affected Turkey, thus making the security stabilization in Iraq number Turkish foreign policy priority (Tziarras, 2014). Because of proximity, the Kurdish issue and Iraq posed a threat to Turkey, the very reason the Turkish Parliament rejected the US request to open a front in Turkey. Security concerns are the reason Turkey deepened ties with Iran and Syria. The Kurdish question united the three states, as evidenced by Iran and Turkey, cooperating militarily to contain the PKK operations in North Iraq (Tziarras, 2014). Similarly, Syria, which also shares similar the Kurdish problem, supported Turkey's operations in North of Iraq. The unresolved Kurdish problem has constrained Ankara's new policy as a role model to the region (Grigoriadis, 2010).

Turkey has become increasingly focused on the Middle East because of the role the region plays in the Turkey's security interests and in the Turkey-EU/US diplomatic relations (Tziarras, 2014). Turkey perceives the PKK as a threat to stability. The new foreign policy of Turkey was initially characterized by a gradual reduction in the discourses regarding national security. Under AKP regime, the foreign policy focused on zero-problems with neighbors. This approach focused on addressing Turkey's major problems with neighboring countries via bilateral cooperation, negotiations, and close economic ties (Tziarras, 2014). This proactive diplomacy outlook elevated Turkey to peace-keeping and order-instituting role in the region. With this objective, Turkey mediated disputes between Israel and Arab countries, such as Palestine groups and Syria.

So the Kurdish issue both inside and outside the country has been always a real constraint in front of Turkish foreign policy, so since 2003 invasion of Iraq, Turkey has the weariness of Kurdish complete divorce from Iraq, however still Turkey and KRG built strong diplomatic ties, and these strong ties essentially owe the Turkish new driving forces speculated toward Middle East, as economy, soft instrumental polices and security emphasis, because after the Arab uprisings Turkey fell among a dilemma of unsecured countries and territories, so KRG was always a better option for Turkey to continue on strong relations.

\section{CONCLUSION}

The relations of Turkey with KRG took its official status since 1991, and Turkey has always preferred to have stable relations with KRG, and this was more obvious when AKP has come to power and they made serious attempts in solving Kurdish issue inside Turkey, and this has been directly affected the relations with KRG. On the other hand security has always been a determinant factor for Turkey in choosing friendly relations with secure territories. But Referendum actually was not a new issue, it has been discussed since 2013 when ISIS started to arise, and due to unresolved issues between Erbil and the central government, referendum was one of the options for KRG. Before referendum there were very strong relations between 


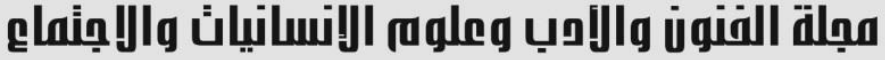 \\ Journal of Arts, Literature, Humanities and Social Sciences www.jalhss.com \\ Volume (54) July 2020 \\ العدد (54) يوليو 2020}

Turkey and KRG, but after the referendum some deteriorations could be noticed, and there were assumptions that may the relations ruin completely.

What it can be derived from the above explanations and analysis, there were deterioration temporarily in the relation of Turkey and KRG, however Turkey was still emphasized on the concerns of economic ties, soft instrument foreign policy and security issues. Additional to that there are many other facets that relate both sides to have mutual interests, and diplomatic relations. It is true that during AK Party government a stable and obvious improvement could be noticed in the relations and, at times, arrived to the highest peak. However, holding referendum by the KRG has made the Turkish officials to reevaluate their relations all over. However holding referendum did not had such an impact on halting the driving forces of Turkish foreign policy, because AKP since has come to power have driven by policies of its economic ties, soft instrumental policies such as cultural ties, and the most important is security issues, and Turkey is a security centered country, by holding referendum, Turkey has escaped for taking such risks and put its security in a threat, so gradually the relations started to normalize especially after the Presidential elections of Turkey, the Prime Minister of KRG Nechirvan Brazani had invited for the inaguration ceremony by Turkey, this highlighted a step forward in normalizatng the relations between two sides.

\section{References}

1. Akçay, B. and Yilmaz, B., 2013. Turkey's accession to the European Union political and economic challenges. Lanham, MD: Lexington Books.

2. Aktas, G. Y., 2010. Turkish Foreign Policy: New Concepts and Reflections. Master Thesis: Middle East Technical University.

3. Candar, C., 2013. Turgut Özal Twenty Years After: The Man and The Politician. Insight Turkey, 15(2), pp. 27-26

4. Davutoglu, A., 2008. Turkey's Foreign Policy Vision: An Assessment of 2007. Insight Turkey, 10(1), pp. 77-96.

5. Demir, Y., 2017. Turkey's foreign policy towards the Middle East under the shadow of the Arab Spring. Newcastle upon Tyne, UK: Cambridge Scholars Publishing.

6. Dogangil, S. G., 2013. Analysing Turkish Foreign Policy Under the AKP Governments Between 2002 and 2013: Is Turkey Moving Away From The European Union?. Master Thesis: London School of Economics and Political Science (LSE).

7. Elhusseini, F., 2018. The Arab Spring effect on Turkey's role, decision-making and foreign policy. Newcastle upon Tyne, UK: Cambridge Scholars Publishing. 


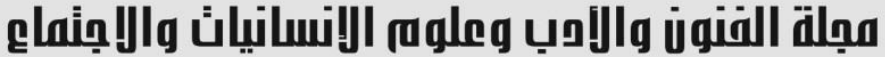

Journal of Arts, Literature, Humanities and Social Sciences

wWw.jalhss.com

8. Grigoriadis, I. N., 2010. Davutoglu Doctrine and Turkish Foreign Policy. Hellenic Foundation For European and Foreign Policy (ELIAMP), April.pp. 111.

9. Gursoy, Y., 2010. Democratization and Foreign Policy Reforms in Turkey: Europeanization of Turkish Politics?. International Journal of Legal Information, 38(2), pp. 227-234.

10. Heper, M., 2013. Islam, Conservatism, and Democracy in Turkey: Comparing Turgut Özal and Recep Tayyip Erdoğan. Insight Turkey, 16 September, 15(2), pp. 141-156.

11. Huseyin Bagci and Suay Nilhan Acikalin, 2015. From Chaos to Cosmos: Strategic Depth and Turkish Foreign Policy in Syria. In: Chaos, Complexity and Leadership 2013. Ankara: Springer, pp. 11-25.

12. Inat, K., 2014. Transformation of Turkish Foreign Policy Capacity: The AK Party Era. Turkish Journal of Middle Eastern Studies, pp. 1-24.

13. Kara, M., 2011. 'Axis Shift' in Turkish Foreign Policy during AKP Administration: New Fundamental Foreign Policy Principles and Challenges. Master of Arts in International Relations: East Mediterranean University.

14. Karatasli, S. S., 2015. The Origins of Turkey's "Heterodox" Transition to Neoliberalism: The Ozal Decade and Beyond. JOURNAL OF WORLDSYSTEMS RESEARCH, 21(2), pp. 338-416.

15. Khalifa, M., 2017. Turkish Foreign Policy in the Middle East After Arab Spring. International Relations and Diplomacy: David Publishing, Volume 5, pp. 102-111.

16. Malinauskas, A., 2015. Turkey's foreign policy preferences and the impact of first direct presidential elections. Russian Journal of Political Studies, 2(2), pp.61-66.

17. Reynolds, M. A., 2012. ECHOES OF EMPIRE: Turkey's Crisis of Kemalism and The Search For An Alternative Foreign Policy. Saban Center for Middle East Policy at Brookings and Center on the United States and Europe at Brookings, pp. 1-33.

18. Tashjian, Y., 2012. From Conceptualization to Implementation and Revaluation: Turkey's "Strategic Dpeth" in the MENA Region. Strategic Outlook: Adequatio intellectes et rei, pp. 1-27.

19. Turan, K., 2012. Changes in Turkish Foreign Policy: A Shift or a Passing Interest. Akademik Bakis, 6(11), pp. 65-84.

20. Tziarras, Z., 2014. Turkish Foreign Policy Towards the Middle East Under The AKP (2002-2013): A Neoclassical Realist Account. PhD Dissertaion: The University of WARWICK.

21. Yuksel, U., 2016. Change and Continiuty: Turkish Foreign Policy Since 2002, Under the Justice and Development Party (Adalet ve Kalkinma Partisi-AKP). CUNY Academic Works, pp. 1-65. 